\title{
HENRY PHILLIP FOLLAND \\ O.B.E., F.R.Ae.S., F.I.Ae.S., F.R.S.A. 1889-1954
}

\section{A TRIBUTE}

$\mathrm{W}$ ITH THE PASSING of Harry Folland, British aviation has lost one of its most distinguished designers of fighter aircraft during the formative period between the two world wars.

Henry Phillip Folland was born at Cambridge on 22nd January 1889 and, like many other boys of his time, he became intensely interested in motor cars. He went to Coventry and served an apprenticeship at the Lanchester Motor Company and stayed on in the town afterwards. I first knew him when he was on the drawing board at the Daimler Company.

While in Coventry, he became interested in aircraft and model aeroplanes, and eventually in 1912 he, together with several other engineers from the Daimler Company, was attracted down to Farnborough to the Royal Aircraft Factory, the new Government department which had recently been set-up, under the leadership of Colonel O'Gorman, on the site of the old balloon factory near Laffans Plain. There is no doubt that history has shown that this was a unique place, and you can hardly turn anywhere in British aviation without finding that the good things that were done on aircraft between the two wars stem almost entirely from engineers who had been at this remarkable place, and who were inspired by an outstanding leader.

While there, Folland was associated with F. M. Green, the Chief Engineer, who also came from Daimlers, and he became a section leader in the Design Office on single-seater fighters, developing the S.E.4 and later the S.E.5, which went into production and was the most advanced British single-seater fighter at the end of the 1914-18 War. In 1917 there occurred the astounding Public Enquiry, in the middle of a major war, into the Royal Aircraft Factory, which was, in fact, the first murmuring against a nationalised industry. At the time, the disbanding of the technical staff as a result of this enquiry looked like being a major disaster, but it turned out to be a blessing as people like Folland, who had had a splendid grounding on all matters of aeronautical design, had to go out into industry and find a job for themselves.

Folland joined the Nieuport Company at Cricklewood with two other Farnborough people, HeckstallSmith and Hall (later Chief Engineer of Imperial Airways), and designed two or three successful types of machine towards the end of the war. He produced the Nieuport "Nighthawk" fighter and was in the course of designing an interesting plywood, tri-plane, twin-engined bomber when peace was proclaimed and the Nieuport Company, a financial venture of the Waring Group, which had been started for aircraft subcontracting work during the war, was wound up and Folland and his assocrates again found themselves looking for a job.

This time he was more fortunate, and he took his small team to the Gloucestershire Aircraft Company, an off-shoot of H. H. Martin, the famous Cheltenham architectural specialists. Their aviation subsidiary was

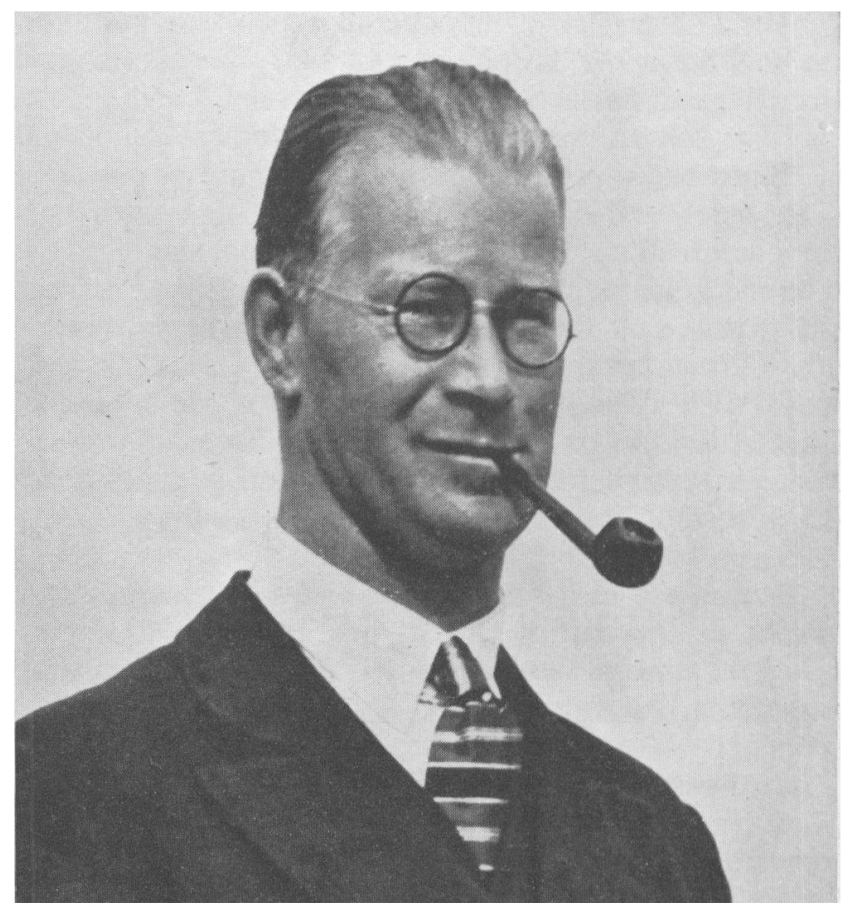

formed during the war to manufacture D.H.4 wings and other components, but they decided after the war to try to remain in the aircraft business.

H. E. Preston, his faithful henchman, who had followed him from Farnborough to Cricklewood, came also and remained Folland's chief technical man without a break for 35 years; the Gibson brothers, still in the Gloster design office today, were also among the small band who put their faith in Folland.

The new Gloucestershire design team's first success was the Gloster I Bamel racer, with a Napier engine, which won the Aerial Derby, and several other events.

From the production point of view, there followed four successful biplane fighters, the Grebe, which was a productionised version of the Nighthawk, the Gamecock, the Gauntlet, and the Gladiator. All these machines went into considerable production for the Royal Air Force, and built up an enviable reputation, the Gladiator doing yeoman service in the early days of the Second World War. It was the first British machine to destroy an enemy aircraft. Three of them put up a wonderful show in the defence of Malta, while a handful did well in the abortive invasion of Norway, operating from a frozen lake. All this series of fighters was immediately recognised in the air by the Folland hall-mark, and in this family of air-cooled, radial, single-seater fighters Folland and his team specialised on neat and painstaking detail design, weight-saving, harmonised controls, and gradual refinement of form.

Following on the Bamel success, Folland undertook a series of racing machines, the Gloster III, IV and VI. The Gloster III was a British challenger at Baltimore, U.S.A. The Gloster IV was, I think, the finest biplane design that was ever produced. It was flown in the 
Schneider Trophy race in 1927 at Venice by Kincaid, and did the fastest lap, but unfortunately had an engine failure and a forced landing, and did not finish the race.

The Gloster VI, a monoplane which was built for the final Schneider Trophy race of 1931, was also a very attractive and finished design. It did a remarkable speed, but was out of the picture because other competing machines had more than 50 per cent. more power.

Folland and his design team put a tremendous amount of effort into this series of Schneider Trophy racers and the machines were superbly finished. It was unfortunate that they were not afforded a better opportunity for success.

In 1929, the company changed its name to the Gloster Aircraft Company and moved from its original works in Cheltenham, adjoining Lansdown Station, to Brockworth Aerodrome, Folland becoming Chief Engineer.

During the next few years, he developed a number of new and promising prototypes, including a singleseater monoplane fighter and a twin-engine fighter, and also took a deep interest in the Heleshaw variable-pitch propeller.

In the early 'thirties, I think Folland became somewhat frustrated and worried about his future, and I remember so well dining with him at Maidenhead on the way home from a Royal Air Force Pageant, and his unfolding to me his dreams for the future and the great urge he had to set up his own company. This dream eventually came true in 1937, and he took over the fine buildings at Hamble, near Southampton, of the defunct British Marine Company. He moved there in the autumn of that year with the same nucleus team, and he set to work with tremendous energy and enthusiasm to build up an organisation.

His natural desire and flair was to create a new design of aircraft and he put in several, but the only order for his own design he received from the Air Ministry was for a small batch of high-altitude Test Bed machines. This I do not think was Folland's fault, as by this time the re-armament drive for the R.A.F. was in full swing and new types had been selected and frozen for production.

Undoubtedly it showed the character of the man that he was able, with his good engineering sense and technical background, to throw himself whole heartedly into the works side, and to take on a number of sub-contracts such as for Blenheim and Spitfire, so that by the time the war broke out he had built up a really good production set-up. No doubt he benefited by his racing experience in taking this balanced and sensible line, because I know he always felt that his Schneider Trophy effort, extremely good though it was, had detracted from his day-to-day current "bread and butter" production work. In 1942 he did produce a most promising aircooled fighter in the true Folland tradition, but the design team responsible for it was taken from him by the powers-that-be of that time, which I know he felt very much indeed.

Throughout the war, however, Folland put in a prodigious amount of work and built up an enviable reputation for sound engineering and production technique. His total force rose to over 3,000 work people, and he took on a big range of work, including complete Spitfire wings, Wellington nacelles, and so on.

At the cessation of hostilities, he laid his works plans carefully for the future and was able to keep his factory going on a number of post-war subcontracts. He also had a small design team running under Preston, which made some project investigations into both military and civil types, but I felt his great enthusiasm and drive on design had gone.

I saw quite a bit of Folland during this period, and I always thought his great effort during the war had overtaxed his strength. The many responsibilities of building up an organisation of this kind in such a short time, and without many senior people round him, had told upon him, and in 1951 he had to step down, which he did with dignity and grace, and was fortunate to have W. E. W. Petter to succeed him.

Folland was a very human and kind man. No one could come into close touch with him without appreciating these qualities. He was always approachable, and there are many who have had a helping hand from him. He was capable of rising to great heights if he was given the opportunity and inspiration. $\mathrm{He}$, in his turn, had the great gift of leadership, and he inspired loyalty and friendship among his colleagues and staff.

An early football accident to his ankle caused him difficulty all through his life. This did not prevent him from taking an interest in games and sport, and playing a reasonable game of golf and bowls. Of recent years he was generally to be seen at the Cheltenham Cricket week with the inevitable pipe and a rose in his buttonhole, having become a keen gardener.

His wife and two sons-both in the Aircraft Industry - survive him. He and Mrs. Folland were actually with their youngest son at Nottingham, when he passed away last September.

He was made a Fellow of the Royal Aeronautical Society in 1920, and took an interest in the local Gloucester and Cheltenham Branch of the Society.

In accordance with his will, his ashes were recently scattered by an R.A.F. pilot over Laffans Plain, the scene of his early triumphs.

Thus has passed, at the age of 65 , one of our most distinguished British aircraft designers between the two wars. A man who had the capacity of imparting great enthusiasm to his staff and inspiring attention to detail and good design. His first love was undoubtedly the single-seater land fighter. He had not the time to give a great deal of attention to larger machines or civil aircraft, but his twin-engine survey machine, however, which really could fly long distances on one engine, did much valuable work.

It is a great satisfaction to his many old friends that towards the end of his life he was afforded the opportunity to realise his dream and build up his own firm and make a success of it, although not from a design point of view, but from the manufacturing and production angles. It is believed that the Folland hall-mark has gone into the Hamble factory and a tradition built up which may well lead on to great things for the future.-ROY FEDDEN. 